\title{
Table of Conventions
}

1856 Declaration Respecting Maritime

Law 101

1907 Convention (VI) Relating to the Status of Enemy Merchant Ships at the Outbreak of

Hostilities 42,101

1907 Convention (VII) Relating to the Conversion of Merchant Ships into War-Ships 42,101

1907 The Convention (XI) Relative to Certain Restrictions with Regard to the Exercise of the Right of Capture in Naval War ..... 42, 102 1907 Convention (XII) Relative to the Creation of an International Prize Court 42, 102

1909 Declaration Convening the Laws of Naval War 102

1910 Convention for the Unification of Certain rules with respect to Assistance and Salvage at Sea $100,113,128$

1948 Universal Declaration of Human Rights 76, 198

1950 European Convention on Human Rights $76,198,203$

1956 UNESCO Recommendation on International Principles Applicable to Archaeological Excavations 232,233

1954 Convention for the Protection of Cultural Property in the Event of Armed Conflict ..... 115, 233

1958 Convention on the Territorial Sea and Contiguous Zone ..... 104 1958 Convention on the Continental Shelf 104
1958 Convention on the High Seas 104

1958 Convention on Fishing and Conservation of the Living Resources of the High Seas . 104

1967 Protocol to amend the Convention for the Unification of Certain Rules of Law Relating to Assistance and Salvage at Sea 140

1969 European Convention on the Protection of the Archaeological Heritage 206

1969 International Convention Relating to Intervention on the High Seas in Cases of Oil Pollution Casualties ...... 113, 187

1969 International Convention on Civil Liability for Oil Pollution Damage (CLC Convention) 187

1970 UNESCO Convention on the

Means of Prohibiting and

Preventing the Illicit Import, Export and Transfer of Ownership of Cultural Property $115,228,233$

1971 International Convention on the Establishment of an International Fund for Compensation for Oil Pollution Damage 187

1972 Convention Concerning the Protection of the World Cultural and Natural Heritage .... 115, 233 1972 Convention on the Prevention of Marine Pollution by Dumping of Wastes and Other Matter ...... 140 1980 Vienna Convention on the Law of Treaties 97, 98, 218 
1982 United Nations Convention on the Law of the Sea 74 , 103-112

1989 International Convention on Salvage $76,100,128$ 1992 European Convention on the Protection of the Archaeological Heritage ...... 203, 206

2001 Convention on the Protection of the Underwater Cultural Heritage
(UCH Convention) ...... 3, 4, 115, 116, 120, 193, 214, 235, 272, 275, 290

2003 Convention for the Safeguarding of the Intangible Cultural Heritage ................................. 115

2004 UN Convention on Jurisdictional Immunities of States and Their Property 100,140

2007 International Convention on the Removal of Wrecks ........ 140 